This is the accepted version of a forthcoming article in Review of Political Economy published by Taylor $\&$ Francis: http://www.tandfonline.com/loi/crpe20

Accepted version downloaded from SOAS Research Online: http://eprints.soas.ac.uk/25262/

\title{
Marx 200: The Abiding Relevance of the Labour Theory of Value
}

Ben Fine $^{\mathrm{ab}}$ and Alfredo Saad-Filho ${ }^{\mathrm{cl}}$

aSOAS University of London, London, United Kingdom; ' Institute of Social and Economic Research, Rhodes University, Grahamstown, South Africa; 'SOAS University of London, London, United Kingdom.

\begin{abstract}
Marxist political economy is alive and well, and not just because of the habitual turn to Marx in response to any crisis of capitalism. Both through Capital and through the continuing evolution of Marxism, Marxist political economy offers valuable insights that can illuminate the modalities of social and economic reproduction and the relationships between (different aspects of) the economic and the non-economic. Marxism's presence has been felt through its own internal debates and debates with other approaches to political economy, and even through its influence on those reacting against Marxism. The key to the continuing relevance and analytical strengths of Marxist political economy lies in its capacity to provide a framework of analysis for unifying disparate insights and critiques of the contradictions of capitalism across the social sciences. The instrument for forging that unity is Marx's theory of value, the potential of which is examined and illustrated with reference to the Sraffian critique and two key concepts in Marxian political economy, the value of labour power and financialisation. They are explored in the light of the processes of commodification, commodity form and commodity calculation.
\end{abstract}

\section{ARTICLE HISTORY}

Received 14 August 2017

Accepted 30 December 2017

\section{KEYWORDS}

\footnotetext{
${ }^{1}$ CONTACT Alfred Saad-Filho as59@soas.ac.uk; Department of Development Studies, SOAS University of London, London, United Kingdom.
} 
This is the accepted version of a forthcoming article in Review of Political Economy published by Taylor $\&$ Francis: http://www.tandfonline.com/loi/crpe20

Accepted version downloaded from SOAS Research Online: http://eprints.soas.ac.uk/25262/

Marx's theory of value, value of labour power, financialisation, commodity, commodity form, commodity calculation.

\section{JEL CODE}

B14

\section{Introduction}

Marxist political economy (MPE) experiences a rhythm and evolution in terms of both its prominence and (perceptions of) its substantive content. More recently, MPE has witnessed a revival in the wake of the Global Financial Crisis (GFC), just as it did when the post-war boom came to an end. No doubt the $150^{\text {th }}$ anniversary of the publication of Volume I of Capital and the $200^{\text {th }}$ anniversary of Marx's birth will add to this process. However, this is necessarily different from the Marxisms that were prominent before 1917, in the interwar period, after 1956 or post-1968. This is, in part, because influential social theories are moulded by, just as they mould, their own social and historical context. While this is not the place to detail our interpretation of MPE, its relationship to economic heterodoxies, and why MPE remains relevant for understanding neoliberalism as the current stage of capitalism, ${ }^{2}$ it is important to note that the dynamic and content of MPE are unique, uniquely influenced, and uniquely influential.

First, given its attachment to working class social and political perspectives, the revolutionary abolition of capitalism and the transition to communism (each of which has been conceptualised in different ways within the Marxist tradition, and over time), the fortunes of Marxism are, inevitably, tied to the strength, balance and composition of progressive forces across the globe. Over the past forty years, these have been unfavourable for several well-known reasons: the rise of neoliberalism and financialisation under US hegemony, however understood, the global restructuring of production, regressive shifts in economic policy, the collapse of Soviet-style socialism, the transformations in China, the hiatus and limitations of national liberation movements, the fragmentation of left political parties, the shrinking membership and influence of most trade unions, and so on. The

\footnotetext{
${ }^{2}$ For details, see Fine (2012a), Fine and Saad Filho (2017), Fine, Bayliss, Robertson and Saad-Filho (2018) and Saad-Filho (2017).
} 
This is the accepted version of a forthcoming article in Review of Political Economy published by Taylor $\&$ Francis: http://www.tandfonline.com/loi/crpe20

Accepted version downloaded from SOAS Research Online: http://eprints.soas.ac.uk/25262/

commendable emergence of new movements, such as feminism and environmentalism, have not compensated for the decline of more traditional forms of struggle, and they tend to have a mixed relationship to MPE. ${ }^{3}$ Consequently, there has been a noticeable erosion of the impulse to Marxism in the 'age of neoliberalism', despite a recent upsurge.

Second, Marxism adopts a holistic or systemic approach, placing it outside the orbit of neoclassical economics. This is not only because of the latter's methodological individualism of a special type but because of its constituting the economic as a fetishised category in its own right, independent of its social and historical context. The latter also distinguishes MPE from much heterodox economics, with MPE's grounding in production equally distinctive from Keynesian approaches.

Third, MPE has become increasingly confined within academic life and scholarship, where it has been, at least partly, fragmented across traditional disciplinary lines and subjected to standard professional evaluation criteria while, at the same time, continuing to be rejected by mainstream economists for its presumably flawed economics and for failing the tests of mathematical and statistical rigour, and by non-economists for its presumed economism and reductionism. Even within heterodoxy, critiques of MPE often proceed on the basis of stylised or even ignorant understandings of MPE's content. In short, Marxism and its political economy are often subject to a careless reconstruction at the hands of those who both criticise and deploy it, removing it far from its original content and intent.

Fourth, there are increasing signs of dissatisfaction with the orthodoxy and a growing search for alternatives among those studying economics and the other social sciences, not least with the demands for heterodoxy and pluralism in the teaching of economics. This impulse has been supported by material developments, including the growing realisation that environmental degradation is intimately related to capitalism; the aftermath of the collapse of the USSR and the recognition that capitalism has not furnished a progressive alternative even on its own terms, and the eruption of imperial wars and occupations, even if fought under the guise of anti-terrorism or human rights.

While these distinguishing elements of Marxism, and its dynamics in practice, have often led to its marginalisation, MPE has also withstood the tests of both hard times and intellectual prejudice. For example, because of its emphasis on modes of production, class and the historical, and its attention to considerations of power, conflict, and the systemic,

\footnotetext{
${ }^{3}$ See the surveys in the Socialist Register 2012, 2017, and the relevant entries in Fine and Saad-Filho (2013) and Brennan et al (2017). Note, also, the parallel decline in the labour process literature.
} 
This is the accepted version of a forthcoming article in Review of Political Economy published by Taylor $\&$ Francis: http://www.tandfonline.com/loi/crpe20

Accepted version downloaded from SOAS Research Online: http://eprints.soas.ac.uk/25262/

Marxism is genuinely interdisciplinary, with Marx himself offering the richest of contributions across an impressively wide range of fields within (and beyond) the social sciences. These not only provide a fertile body of work upon which continuing scholarship can draw but also the opportunity for the rediscovery and renewal of interpretations of the classics of Marx and Marxism under changing circumstances. This allows MPE to sustain an insightful, critical and constructive presence within and across disciplines and topics, and to retain its broader appeal. This is true for objects of study ranging from the economic to the ideological, and from the most detailed at the local level to the fate of the contemporary world.

MPE has much to offer in two further directions. One is in the critique of all versions of economics, recalling that Marx's own magnus opus, Capital, is subtitled A Critique of Political Economy, with himself dissecting, in the Theories of Surplus Value and elsewhere, the degradation of political economy into the vulgar economics that prevails today. Further, MPE establishes a presence within, influence on, and critique of, each of the social sciences as well as specific topics straddling disciplinary boundaries (the state or globalisation, as well as the political, the sociological, the historical, the geographical and the anthropological).

Despite these advances, in at least one respect MPE is in the doldrums, especially by comparison with the earlier period of major economic crisis. For the 1960s and 1970s witnessed an extraordinary lively set of debates around the fundamentals of MPE, focusing on methodological, conceptual and theoretical issues and their relevance for the contemporary period as part of a wide-ranging attempt to restore the full scope of the theory after the decades of Stalinism and McCarthyism. ${ }^{4}$ Nothing similar has occurred currently even though debates around Marx's method, the transformation problem and the falling rate of profit are still subject to new airings. ${ }^{5}$

One reason for this relative stagnation is that earlier debates highlighted major points of interest while, simultaneously, flogging any theoretical differences almost to death even if none was resolved to the satisfaction of those at one or other end of the duelling positions. The long period of relative stagnation following the breakdown of the post-war boom suggested that capitalism could engage in business as usual even if on a sluggish basis. The GFC shattered this perspective, as it brought to the fore the prominent role played by finance

\footnotetext{
${ }^{4}$ See Fine (1986), Fine and Harris (1979), Howard and King $(1989,1991)$ and Saad Filho (2002). It is significant that more recent such surveys are few and far between, primarily because MPE has become more fragmented and spread across positions and subject matter.

${ }^{5}$ Most recently, Moseley (2015) and Shaikh (2016).
} 
This is the accepted version of a forthcoming article in Review of Political Economy published by Taylor $\&$ Francis: http://www.tandfonline.com/loi/crpe20

Accepted version downloaded from SOAS Research Online: http://eprints.soas.ac.uk/25262/

in contemporary capitalism. Since then, critical thought has turned towards the nature of contemporary capitalism, as reflected in the rise of such concepts as neoliberalism, financialisation, globalisation and social capital. Inevitably, the result is to raise the question of the economy outside economics, and to seek guidance from political economy.

Yet, at least until recently, much social theory missed these important developments in contemporary capitalism. Our contention is that that failure was not because MPE has been inappropriate for, or incapable of, addressing these new developments. On the contrary, it is vital for that purpose, as will be illustrated by reference to two core concepts, interest bearing capital (IBC), as the foundation of financialisation, and the value of labour power (VLP).

This is explored below, in seven sections. This introduction is the first. The second examines the structure, meaning and relevance of MTV for contemporary capitalism. The third reviews the Sraffian critique of MPE, in order to highlight the structure and goals of Marx's analysis. The fourth reviews Marx's theory of VLP, in view of the most significant views in the literature, and their implications for a dynamic understanding of VLP. The fifth analyses the development and significance of financialisation for neoliberal capitalism, in the light of original Marxian categories, especially IBC and fictitious capital. The sixth brings the previous sections together, in the analysis of commodification, commodity form and commodity calculation. The seventh concludes.

\section{The theory of value}

The theory of value occupies a central place in MPE. Its centrality is indicative of the rich content with which value theory is endowed, which requires that value theory be rejected as simply constituting a theory of price based on a technical definition of the quantity of labour embodied in a commodity. ${ }^{6}$ Instead, Marx's theory of value (MTV) seeks to trace out how labour-time exercised within capitalist production is attached to market forms, and its consequences. That is, value is a social relationship between producers expressed, through the market, as a physical relationship between things (or in various forms of equivalence as monetary magnitude). From this point of view, value theory traces the relations, structures, agencies and processes by which market forms emerge, evolve and are reproduced, and locates them in their historically- and socially-specific contexts. As this is not a matter of

\footnotetext{
${ }^{6}$ For an exposition, see Fine and Saad-Filho (2016).
} 
This is the accepted version of a forthcoming article in Review of Political Economy published by Taylor $\&$ Francis: http://www.tandfonline.com/loi/crpe20

Accepted version downloaded from SOAS Research Online: http://eprints.soas.ac.uk/25262/

right or wrong, but of material reality, the challenge is one of reproducing the structures, processes, relations and agencies in thought.

Focus upon uncovering the market forms within capitalism, rather than taking them for granted, offers the opportunity for general analysis of the mode of production in terms of its economic categories. In this respect, Marx endowed us with a rich body of theory, addressing value in the complex context of economic and social reproduction and the (laws of the) accumulation of capital. It follows that MPE does not proceed from the economy or the economic in the abstract through ideal and universal categories (attached, for example, as in neoclassical economics, to scarcity, technology, endowments and preferences). This approach should suffice to dismiss neoclassical or Sraffian interpretations of Marx (see below), that view value theory as a, generally inadequate, ideal theory of (equilibrium) price or, even if more favourably inclined, impose ideal fixes to value theory, rather than selecting and reproducing material processes in thought in order to trace out the complexity of actual value relations.

It is, then, hardly surprising that controversies over abstract issues such as the transformation problem should prove so bitter, pervasive and long lasting, for they reflect big differences in interpretations of Marx as well as his method. By the same token, if anyone has been lucky enough to get the solution right (and plenty believe they have), there is no guarantee that such virtue will extend into other areas of application.

Consequently, of necessity, MTV is both selective and incomplete, for two reasons. On the one hand, there are multiple determinants in the passage from production through to exchange, use and reproduction. Marx's own pre-occupation, as a reflection of capital within its most advanced stage at his own time of writing, is with the formation of exchange relations as productivity is enhanced through accumulation of capital (both transformation of value into prices of production and law of the tendency of the rate of profit to fall), and the distribution of surplus value in the form of industrial and commercial profit, interest and rent. Whilst quantitative relations are involved, the prior if not primary concern is with the appropriate logical derivation of categories, their location in the structure of abstraction, and the nature and structure of causation. Thus, Capital Volume I focuses on the production of surplus value, Volume II with its circulation, and Volume III with its distribution and movements as a whole, giving rise to interest, rent and the punctuation of accumulation by crises. In addition, the Theories of Surplus Value critically dissect how corresponding 
This is the accepted version of a forthcoming article in Review of Political Economy published by Taylor $\&$ Francis: http://www.tandfonline.com/loi/crpe20

Accepted version downloaded from SOAS Research Online: http://eprints.soas.ac.uk/25262/

categories are deployed in classical political economy, that is, how capitalism presents itself to Marx's contemporaries and predecessors.

On the other hand, whilst the texts mentioned above are replete with empirical and historical illustration, logically derived analyses - including the difference between productive and unproductive labour, the nature of IBC, and the impact of landed property can only be taken so far before historically-specific developments must be incorporated. What is productive or unproductive labour, for example, can readily be specified logically, although there may be differences over this, but it does not always locate analytically transport workers or state employees in a state-owned industry once and for all. As with value theory more generally, such conundrums lead some to reject and others to insist upon it. We fall into the latter camp and hope to illustrate why and how, by reference to the Sraffian debates, value of labour power and financialisation.

\section{Sraffianism: One step back, no steps forward}

In the 1970s, debate over MTV was fought more widely than at any time before or since, engaging those situated within Marxist, heterodox and mainstream economics. Although it also spilled over into debates over falling profitability and the distinction between productive and unproductive labour, at the heart of the debate was the so-called transformation problem, in which it was argued not only that Marx was wrong but, often, that the concept of value as labour time is invalid because, for example, values can become negative in the presence of joint production of which fixed capital and its depreciation is an unavoidable example (Steedman 1977, 1981).

From this point of view, the whole edifice of Marx's political economy collapses from the simple reality of fixed capital (ironical in view of the attention that Marx devotes to its role both in production and circulation). From our perspective, exposed at the time of the debate (see, for example, Fine 1986, and Fine and Harris 1979), this involves a misunderstanding of value relations, in which value is created by concrete labour in production (and so can hardly be negative) but is expressed through exchange relations. There can be no presumption that each piece of concrete labour can be assigned to a single commodity, or mix of commodities, or a single piece of value.

It is striking how this debate not only failed to persuade many to change sides - you either were committed to equilibrium price theory or not, although some straddled the divide 
This is the accepted version of a forthcoming article in Review of Political Economy published by Taylor $\&$ Francis: http://www.tandfonline.com/loi/crpe20

Accepted version downloaded from SOAS Research Online: http://eprints.soas.ac.uk/25262/

(most recently, Moseley 2015; see also Fine 2017d) but also how the debate simply died. This might be attributed to the general decline in heterodox political economy, but there is a deeper theoretical reason: the equilibrium approach has nowhere to go in terms of further analysis. For, it is negative both in the sense of denying Marx's value theory and in depending upon equilibrium prices for fixed technologies and choice of techniques, which are far removed from the subject matter of MPE (and much heterodox economics as well), in which the dynamics of accumulation and technological change are to the fore.

As Fine (1980) put it, irrespective of the merits of equilibrium analysis, the Sraffian approach tends to conflate two different meanings of 'determination'. One is the ability to calculate what prices will be in some equilibrium world of fixed technology. The other is to question causation - what makes prices and values be what they are, and what is their relationship. To say, as Sraffians do, that technology and wages 'determine' equilibrium prices and profits refers to the possibility of calculation, but it says nothing about causation, just as $\mathrm{y}=\mathrm{x}^{2}$ cannot tell us whether $\mathrm{y}$ is caused by $\mathrm{x}$, vice-versa, or both caused by something else.

This debate damaged MPE by suggesting that MTV is flawed as an equilibrium price theory, whilst offering little to replace it since the presumption of fallacy was based upon assumptions that were as unrealistic and fruitless as those of the mainstream - in this sense, Samuelson (1971) was indistinguishable from Steedman (1977). ${ }^{7}$ Yet, Marx's analysis of the dynamics of accumulation is based on value theory, and more concerned with how surplus value is created and with what consequences for economic and social reproduction, including crises and new phases of capitalism. Thus, value as a context of equilibrium is simply conceptually inadequate.

Thus, whilst Sraffianism sought to kill value theory (which it did to some degree, and continues to wound it through the conventional wisdom that MTV is invalid), it did so through a methodology that garnered no further momentum of its own. At most, it offered a combination of distributional struggle between capital and labour over unexplained productivity gains, complemented by implications for and from effective demand. This approach had only limited capacity to deal with the multiplicity of determinants, causes and effects that lay outside the simple algebra of the neoclassical production function - nor or of

\footnotetext{
${ }^{7}$ Although, of course, the Sraffian system had profound implications for one-sector neoclassical economics and the eponymous production function, as accepted by Samuelson (1966) if not his successors, see Fine (2016).
} 
This is the accepted version of a forthcoming article in Review of Political Economy published by Taylor $\&$ Francis: http://www.tandfonline.com/loi/crpe20

Accepted version downloaded from SOAS Research Online: http://eprints.soas.ac.uk/25262/

similarly understood value theory, to which it critically moved from the Cambridge

Controversy (Fine 1980). In other words, value theory was closed off and the other fork in the analytical road led to a dead end, which is ironic given the significance of Sraffa's contribution to political economy focusing on increasing returns to scale as opposed to the constant returns in the input-output models of the Sraffian critiques of Marx.

This does, though, raise the issue of the relationship between value theory and more complex economic and social phenomena, such as different capital intensities, that are confronted by the transformation problem. One approach, popularised by Sweezy (1968), is that value theory is an abstraction as a first approximation to reality that must be successively modified to be less approximate as more factors are included (his own inclination being to incorporate the capacity to sell commodities and realise potential surplus, as the next largest step to realism as opposed to equilibrium prices).

From our perspective, this is incorrect. On the one hand, later approximations would invalidate what had come before, rendering it redundant. There would be no point to the initial levels of analysis, given the closer approximation of those coming later. On the other hand, Marx's abstractions are about extracting simple underlying realities from the complex forms in which they present themselves, and showing in developing the theory how those more complex forms confirm the reality of the simpler concepts (e.g., value derives from production because that is where labour is exercised). Such relations unfold both logicallytheoretically, and empirically-historically in MTV.

\section{Value of labour power}

The value and reproduction of labour power occupies a significant position within MPE. Labour power is (re)produced as a special commodity through structures, relations, processes and agencies that do not fall under the immediate power and controls attached to economic reproduction, i.e, the production and circulation of (surplus) value.

The value of labour power (VLP) has been interpreted and deployed in two different ways within MTV, although each draws upon Marx's notion that the purchase of labour power presumes a process of reproduction outside the capitalist sphere, with reliance to some extent on capitalistically produced means of consumption. One definition of the VLP is in terms of physical subsistence, the wage bundle, or the so-called moral and historical elements that make up a customary standard of living, or (social) norms, with different items of the 
This is the accepted version of a forthcoming article in Review of Political Economy published by Taylor $\&$ Francis: http://www.tandfonline.com/loi/crpe20

Accepted version downloaded from SOAS Research Online: http://eprints.soas.ac.uk/25262/

standard having their own norms - food, housing, clothing and so on. Given the use values that comprise VLP so interpreted, there would appear to be a corresponding VLP, determined by the labour time socially necessary to (re)produce them. Alternatively, VLP has been defined as simply a value magnitude, either a sum of money or a share of national income or, identical in principle, a quantum of abstract labour time. This could correspond to a range of different wage bundles according to the consumption decisions of workers.

These two ways of approaching VLP might appear to be compatible. However, tensions arise when we move beyond static analysis associated with simple reproduction. For, with accumulation and productivity growth, the first definition of VLP as a fixed set of use values would mean a declining VLP by the second definition, since the labour time of production of the wage bundle would fall over time. Or, conversely, if VLP by the second definition were applied, together with productivity growth, it would correspond to a continuing increase in the customary standard of living, since more commodities could be purchased as they become cheaper.

No doubt simplifying, for Lebowitz $(2006,2010)$, the resolution of the tension between these definitions of VLP depends upon the 'degree of separation', or the extent to which the working class can overcome its fragmentation across different sites of production and collaborate to appropriate the productivity increases for which they are responsible as (surplus) value producers. This is certainly an influential factor in practice, but it narrows our understanding of social reproduction to just one aspect of economic reproduction, even if adding the element of class struggle. This understanding is limited in three ways. First, the pressures and influences upon social reproduction are played out through complex forms of (class) struggle and alliances, which cannot be reduced to the interplay between the (potentially fragmented interests) of capital and labour. Second, it disregards other determinants of VLP and, third, methodologically, why should these processes be located at the same level of abstraction as the creation of value itself, as a class relation of production? ${ }^{8}$

A different angle of approach to VLP is through the examination of how the moral and historical elements are established (whether as a bundle of use values or as a quantum of value) rather than treating this in a hand-waving fashion - oh, the customary just changed! There is nothing in the value relations attached to economic reproduction that allows us to answer this; instead, research must delve into broader aspects of social reproduction. To put it

\footnotetext{
${ }^{8}$ For a detailed analysis, see Fine $(2008,2013 a)$.
} 
This is the accepted version of a forthcoming article in Review of Political Economy published by Taylor $\&$ Francis: http://www.tandfonline.com/loi/crpe20

Accepted version downloaded from SOAS Research Online: http://eprints.soas.ac.uk/25262/

in a crass way, at what point does a mobile phone become morally and socially customary, as well as all other sorts of commodities and aspects of reproduction including health, education and welfare, patterns of working, what and how we eat, travel, inhabit, etc.

Accordingly, although there must be a correspondence between social norms and VLP, those norms are complex in how they are created and transformed across four dimensions. First, VLP itself, across different workers, sectors, locations, and so on, will reflect different standards, determined by skill, organisational strength, bargaining power, and so on. These determine the nature of the variegated labour markets in a capitalist economy, and how they evolve. ${ }^{9}$

Second, there will be different levels of consumption across the use values that make up VLP. Some will consume more and different than others although this will inevitably reflect differences in access to purchasing power as well as cultures of consumption, to be specified. These norms will differ from one use value to another, possibly relatively limited in case of washing machines but more distinguishable in foods eaten and holidays taken. These differences will also be reflected in forms of provision, whether housing be owneroccupied or (privately or socially) rented for example, and across most aspects of (private and public) consumption, their relative merits, and who gets access to what and in what form.

Third, there will be shifting norms over whether provision is through the (capitalist) market or not, with other forms of provision straddling or lying outside economic reproduction such as through domestic production or provision by the state or even charity. In this way, so-called domestic labour can be seen to be not only a vital component of social reproduction alongside health, care, education and so on, but also to constitute the norms associated with VLP in which the content of each can shift and be transformed, as with commodification and de- and re- commodification. For example, decommodification can derive from the removal of provision either to domestic or to state responsibility, or being contingent upon developments expanding commodification (as in self-entertainment through purchase and use of electronic devices). Thus, state provision may expand markets for capitalist production without being capitalist itself, serving to guarantee realisation as part of to social reproduction.

Fourth, these norms are not determined simply by reference to the working class and its cultures. For the social norms attached to commodity consumption derive in part from the

\footnotetext{
${ }^{9}$ See Fine (2013a).
} 
This is the accepted version of a forthcoming article in Review of Political Economy published by Taylor $\&$ Francis: http://www.tandfonline.com/loi/crpe20

Accepted version downloaded from SOAS Research Online: http://eprints.soas.ac.uk/25262/

income available to spend, which is correlated but not synonymous with wages, as opposed to other forms of income and wealth. In addition, the formation and influence of norms straddles class boundaries even if their levels and forms are heavily conditioned by class (as with owner-occupation, state versus private pension, access to health and education, and so on).

This implies that the determination of VLP and its transformations is a consequence not of some remorseless capitalist logic but of class and other forms of conflict. For example, even if there is some abstract interest of capital in reducing VLP, this still has to be brought about and, inevitably, will involve conflicts of interest between, for example, capitals with higher productivity as opposed to those depending upon cruder forms of exploitation. This means that progressive capitalists may support measures for social beyond economic reproduction, especially in response to, or when struggled for by, an organised working class, potentially with the additional support of progressively-oriented intermediate strata which can also benefit from universal forms of provision.

Further, VLP, and the economic and social reproductions with which it is associated, are subject to major transformations across stages of capitalism. For example, in the post-war Keynesian boom, there was in the advanced economies a coincidence of growth in both commodified and non-commodified provision, as with norms for consumer durables, expanding levels of consumption more generally, and the rise of the welfare state for health, education, pensions, and other elements of social security and well-being. In contrast, over the past three decades the advance of neoliberalism has meant that VLP has been determined in different ways, and not just through class offensive, austerity and so on. Rather, under neoliberalism economic and social reproduction has become increasingly governed by financialisation both directly and indirectly. ${ }^{10}$

\section{Financialisation}

The growth of finance and its presence and influence across economic and social reproduction has underpinned a corresponding growth of the concept of financialisation across the social sciences. ${ }^{11}$ Yet, financialisation is the defining characteristic of the global economy during the past thirty years, and the economic core of neoliberalism. This is a

\footnotetext{
${ }^{10}$ See Fine (2012b, 2014b and 2017b) for (neglect of) relationship between social policy and financialisation.

${ }^{11}$ For its rejection as a buzzword/fuzzword, see Christophers (2015) and Michell and Toporowski (2014).
} 
This is the accepted version of a forthcoming article in Review of Political Economy published by Taylor $\&$ Francis: http://www.tandfonline.com/loi/crpe20

Accepted version downloaded from SOAS Research Online: http://eprints.soas.ac.uk/25262/

relatively new term, which has emerged from, and remains confined within, heterodox economics in general, and MPE specifically. Its absence from orthodoxy is because it is both systemic (i.e. characteristic of the workings of the economy as a whole) and dynamic and, hence, it is not reducible to the optimising, equilibrium and efficiency that are centrally important to the orthodoxy. ${ }^{12}$

Unsurprisingly, financialisation is subject to multiple understandings, both because of the variety of conduits through which finance is connected to the rest of the economy (for example, the proliferation of financial markets, across mortgages and pensions to futures markets in carbon emissions), and because of the ways in which these developments are attached to the evolution of the economy itself. Most analyses of financialisation start from the definition in Epstein (2005, p.3): 'financialization means the increasing role of financial motives, financial markets, financial actors and financial institutions in the operation of the domestic and international economies', but this is an amorphous and all-embracing conceptualisation. Anything to do with monetary relations counts as financialisation, just as any aspect of commodity relations would count as commodification, or any labour would count as value if 'improving' on Marx.

From the perspective of MTV, this is mixing up the production of (surplus) value and the forms it takes, even if those forms can take on a life of their own independent of capital(ism). Although extremely positive in inspiring empirical analyses of financialisation, such an all-embracing definition collapses analytical distinctions and tends to preclude the logical and historically-systemic analyses attached to MPE. This is to suggest that a systematic analysis of financialisation should return to money, through its derivation in Volume I of Capital. In Volume III, at a more advanced level both of analysis and of capitalism itself, money capital becomes a commodity with its price (the rate of interest) deemed 'irrational' because it lacks foundation in the value relations of production, as opposed to the supply of and demand for loanable money capital.

Fine (2014a) argues for a narrow definition of financialisation drawing upon Marx's theory of IBC, that is, capital lent for the purposes of reaping rewards out of profit-making capital. In brief, financialisation is the process of expansion, diversification and integration of the various forms of capital in exchange (in financial and other markets), through assets that

\footnotetext{
${ }^{12}$ See Christophers (2017) and Dymski (2015). Of course, analysis of finance has a strong presence within the orthodoxy, not least with the efficient market hypothesis as critical point of departure for either what might be termed inefficient market hypothesis (informational asymmetries) or, especially in the wake of the GFC, the deployment of behavioural economics.
} 
This is the accepted version of a forthcoming article in Review of Political Economy published by Taylor $\&$ Francis: http://www.tandfonline.com/loi/crpe20

Accepted version downloaded from SOAS Research Online: http://eprints.soas.ac.uk/25262/

straddle the roles of money as credit and money as capital, and their subordination to IBC. This includes the explicit or implicit securitisation of streams of revenue, and the creation of corresponding financial assets that can be traded. That is, financialisation is not the diffusion of consumer loans, but these loans may become financialised if they are traded as what Marx calls fictitious capital, alongside the proliferation of the volume and variety of derivatives.

Such processes have promoted the intensive (within existing spheres of operation) and extensive (incorporating activities where it was previously absent) accumulation of fictitious capital, and increased the scope and prevalence of IBC in accumulation, as IBC has appropriated activities that were the preserve of productive and commercial capital (or not capital at all, as in labour engaged in economic and social reproduction). It follows that financialisation is not a form of (pre-capitalist) usury, and it does not hinge upon the exploitation of (wage) revenue. It is, rather, a contemporary form of incorporation of credit relations into the orbit of fictitious capital. ${ }^{13}$

This approach contrasts with the all-encompassing notions that allow for the presence of more finance of any sort into contemporary life. Instead, the extent and impact of financialisation depend on how financial activity straddles the boundaries between IBC and other forms of capital in exchange, and how it engages with production. Its conceptualisation requires looking at the relationship between productive and money capital, state policies towards banking and finance, and how they have changed over time.

Four implications of financialisation are especially important. First is the dramatic expansion of the range of (speculative) financial transactions, services, institutions, instruments and markets relative to real activity, and the integration and internationalisation of these markets, encompassing ever more areas of economic and social reproduction that were previously provided by the state (for example, housing, pensions, education, health, and economic and social infrastructure).

Second, the increasing predominance of finance over industry, as non-financial companies earn an increasing share of profits from financial as opposed to productive activities. They come to rely less upon the financial system to fund their operations and more on retained earnings or borrowing on open markets, and focus on profits drawn from (shortterm) financial dealing as opposed to seeking long-term productivity gains producing things.

\footnotetext{
${ }^{13}$ See Fine $(2010,2017 a)$.
} 
This is the accepted version of a forthcoming article in Review of Political Economy published by Taylor $\&$ Francis: http://www.tandfonline.com/loi/crpe20

Accepted version downloaded from SOAS Research Online: http://eprints.soas.ac.uk/25262/

Third is the subordination of economic and social policy to the dictates of the promotion of markets, especially of finance. This tends to shift policy towards conservatism, fiscal austerity and commercialisation, and erosion of the institutions, capacity and ethos associated with public provision.

Fourth, all agents - not least the working class - are increasingly embroiled within the financial system. This is whether in pursuit of profitability or within their daily lives.

For these reasons, financialisation has been associated with relatively slow GDP growth rates at least relative to the post-war boom, despite the extraordinarily favourable conditions for growth and productivity increase delivered by neoliberalism, and the prodigious expansion of finance itself (why does the world need three times as many financial services proportionate to the real economy as previously?).

Even though financialisation is associated with growth slowdown and crises at the macroeconomic level, there have been pockets of growth for those who have sheltered themselves from the more dysfunctional forms of finance, used the state to promote (private) accumulation, controlled wages relative to productivity growth, and found both domestic and international markets to serve. In particular, there have been rising returns to the financial sector, and a rising share of income accruing to the holders of financial assets, leading to widening inequalities of income and wealth. At least in principle, these, and the corresponding structures of determination, can be traced through the application of MTV, bearing in mind the realities of contemporary capitalism.

\section{Commodification, commodity form and commodity calculation}

Defining financialisation as IBC allows it to be distinguished from its effects, but the relationships involved have to be traced out. For example, IBC can prevail in the presence of commodification (C), where money is loaned for the purposes of appropriating interest out of the expansion of production undertaken by those borrowing money as capital. In addition, when payments are regular, whether deriving from surplus value or not, they can be securitised and turned into assets for speculative trading (most obvious in mortgage derivatives). In this case, there is no direct expansion of commodity production (most houses will have long since been produced); as a result, reference will be made to the commodity form (CF). What distinguishes financial assets is that they are exchangeable and take on the $\mathrm{CF}$ without being commodities themselves in any normal sense. 
This is the accepted version of a forthcoming article in Review of Political Economy published by Taylor $\&$ Francis: http://www.tandfonline.com/loi/crpe20

Accepted version downloaded from SOAS Research Online: http://eprints.soas.ac.uk/25262/

Three implications follow. First, CF is a logical category derived from and even historically preceding capitalist production. Moreover, many exchanges can take on some of the attributes of commodity exchange without being so, given that money can pay for whatever is available irrespective of whether it has been produced for the market and possible profit (or not even produced at all, as in bribery, gifts, pocket money, etc).

Second, capitalism has a tendency both to impose CF (a leading example would be fees and user charges) and to translate CF into commodity production proper (most notably in the commercialisation and subsequent privatisation of public provision), and to appropriate its activities. For example, expansion in the circulation of value implies ever more revenues available that can be deployed for whatever purpose, not necessarily commodity production. Thus, $\mathrm{CF}$ is not financialisation but it can, like $\mathrm{C}$, provide the raw material for it by securitising associated revenues.

Third, capitalist commodity production is distinct from other forms of production even if money changes hands in their provision. ${ }^{14}$ This implies that, even in the absence of $\mathrm{C}$ or $\mathrm{CF}$, activity may still be governed by monetary considerations, ${ }^{15}$ or what can be termed commodity calculation (CC). Within mainstream economics, for example, cost-benefit analysis seeks to impose monetary calculation in decision-making where the market does not provide prices to do so, or if there are externalities or social costs and benefits that differ from how the market prices them. By the same token, there are shifting and contested boundaries over what is acceptably assessed through CC. ${ }^{16}$ As with the drive to transform CF into $\mathrm{C}$, the same applies for $\mathrm{CC}$ and its transition to $\mathrm{C}$, whether through the intermediate step of $\mathrm{CF}$ or not. Despite such tendencies, capitalism also expands the world of $\mathrm{CC}$, in knowing the price of everything but the value of nothing. ${ }^{17}$

The simultaneous expansions and shiftings across CCFCC is marked most obviously by the rise of the welfare state during the Keynesian period and its privatisation under neoliberalism. Bear in mind that it was traditional to see state provision as both displacing market provision and to provide markets for it! For many analyses, especially of, but not

\footnotetext{
${ }^{14}$ Debate has been fierce over domestic labour in this respect (and productive and unproductive labour) and concerns what does and does not count as (surplus) value as opposed to (surplus) labour in general.

${ }^{15}$ Even as their alter ego, for example, in denying the presence of monetary considerations - as in a wedding at whatever cost, or what money cannot buy.

${ }^{16}$ See Radin (1996) and Zelizer (1994).

${ }^{17}$ There is a false presumption that $\mathrm{C}$ expands absolutely at the expense of $\mathrm{CF}$ and $\mathrm{CC}$, while they tend to expand together; see, for example, Fine (2012c).
} 
This is the accepted version of a forthcoming article in Review of Political Economy published by Taylor $\&$ Francis: http://www.tandfonline.com/loi/crpe20

Accepted version downloaded from SOAS Research Online: http://eprints.soas.ac.uk/25262/

confined to, a Polanyian orientation, this is a matter of commodification, decommodification and recommodification, but such perspectives tend to fail to distinguish between commodification, $\mathrm{CF}$ and $\mathrm{CC}$, just as the amorphous definition of financialisation conflates all monetary forms and influences together.

Nor is this merely of academic or definitional significance, as can be seen by bringing together the categories of financialisation and VLP. For, the distinctions between C, CF and $\mathrm{CC}$ correspond, respectively, to fully-established (private) capitalist production, the presence of charges and hence streams of revenue (which may or may not be privatised and securitised), and the absence of such revenue streams but the incorporation of practices dictated by market logic (as in so-called New Public Management, drawing upon the market mimetics of quantify, $\mathrm{Q}$, evaluate, $\mathrm{E}$, and prioritise, $\mathrm{P}$ - i.e. cut costs/expenditure).

As was indicated above, both $\mathrm{C}$ and $\mathrm{CF}$ allow for financialisation, since there are streams of revenues that can be securitised and traded on financial markets. By the same token, the extension of CCFCC into social reproduction is part and parcel of the reproduction of labour power and the determination of VLP, rather than being limited by capital and its forms. These processes also create those who fall outside their orbit, for example, the hard to employ, house, educate, support with income, and so on. This raises the question of the nature of social reproduction under financialised neoliberalism, both where CCFCC prevails, and where it does not (the rolling back by, and rolling out of, the neoliberal state). ${ }^{18}$ For example, at the same time that the privatisation of social reproduction is being pursued (i.e. its commodification, with the attendant changes in VLP), emphasis has also been placed upon the extent to which domestic labour, particularly of women, has become increasingly necessary to compensate for cuts in social provision due to 'austerity'. Thus, the extension of CCFCC to social reproduction tends to shift social to individualised forms of provision and to create added burdens on women in compensating the withdrawal of sources of income and other forms of material support.

Money, finance, financialisation and VLP have always come together within capitalism, for example, because the wage is the money form of VLP but does not in and of itself provide for its social reproduction. What is distinctive about the contemporary period, and the role of financialisation within it, is the extent to which the latter has intervened in both economic and social reproduction. This can be seen by contrast with the post-war boom.

${ }^{18}$ See Fine and Hall (2012). 
This is the accepted version of a forthcoming article in Review of Political Economy published by Taylor $\&$ Francis: http://www.tandfonline.com/loi/crpe20

Accepted version downloaded from SOAS Research Online: http://eprints.soas.ac.uk/25262/

In this respect, it is worth emphasising how neoliberalism departs from post-war

Keynesianism. Significantly, for the latter, debate amongst progressives was pitched between reformism and revolution and the extent to which the socialising tendencies of capitalism could be sustained. In the event, both have proved unreliable guides to the socialisation of (re)production. For neither of these seem now to be in prospect and, neoliberal ideology to the contrary in terms of its emphasis upon individuation and reliance upon the market, socialisation of economic and social reproduction (and state intervention to promote it) have continued apace through the financialisation that, itself, underpins neoliberalism.

\section{Conclusion}

Locating the social and historical specificity of the capitalist mode of production draws MPE into a broader terrain concerning periodisation both within capitalism and between capitalism and other modes of production. Across these issues we find considerable variation of position, hardly surprising given the grand sweep of material that they cover, with differences over method, its application and the historical processes themselves, and correspondingly distinct interpretations and refinements of Marx's own work and the historical record. In addition, the connection of value theory to the economic and the social, and to the dynamics of change, is a central aspect of MPE that inevitably raises questions of method and methodology. Such questions loom large within Marxism and in its disputes with, and distinction from, other schools of thought.

This article has examined three such aspects of MTV. First is the nature of value itself, as is revealed through the debates driven by the Sraffian critique of MTV. They make it apparent that MTV is not a simple thing, as it traverses methodology, conceptualisation, theory, and the logical and the historical. Accordingly, it cannot be dismissed on simplistic technicalities, as suggested by Sraffianism, whilst also open to varying and deeply contested interpretations in principle and practice.

Second is the determination of VLP as part and parcel of social reproduction, which involves examination of the household, civil society and the state in relation to economic reproduction both logically and historically. In turn, this requires acknowledging the imperatives of capital accumulation, how they are realised, and the role of ideas in forming the social norms underpinning social provision. These factors interact with provisioning itself as well as broader economic and social developments and interests, determining the material 
This is the accepted version of a forthcoming article in Review of Political Economy published by Taylor $\&$ Francis: http://www.tandfonline.com/loi/crpe20

Accepted version downloaded from SOAS Research Online: http://eprints.soas.ac.uk/25262/

cultures of social reproduction. ${ }^{19}$ This is vital in understanding how VLP is endowed with moral and historical elements, as well as the contested meanings of the consumed to the consumer.

Third is financialisation. Both it and VLP occupy very different worlds in contemporary capitalism. From the perspective of MPE, and a holistic methodology, they come together in diverse forms across time, place and activity, in ways which should be traced from values to their forms. Today, in scale and scope if not historically uniquely so, this is apparent in everyday life as has been prominent in the financialisation literature. The connection between VLP and financialisation is forged across different determinants in reflecting and reconstituting the moral and historical elements involved. VLP attaches to CCFCC by virtue of its social reproduction in which financialisation is increasingly influential. So distinctive are money and labour power that they might be dubbed (non-)commodities of a special type, but they share a deep and complex attachment to underlying (value) determinants.

What money and labour power are, then, is heavily conditioned by their relationship to the world of commodities both materially and culturally, and these relationships have to be filled out both logically and historically. This is what Marx does for money in the opening chapters of Capital I and, having laid out the production and circulation of (surplus) value in the remainder of that Volume and Volume II, he offers a structured analysis of finance as capital in exchange in Volume III, ranging over commercial, merchant, money-dealing, loanable and interest-bearing capital.

The systemic relations among social reproduction, finance, industry and the rest of the economy should occupy a prominent place in political economy. With capitalism so demonstrably having failed on its own terms, even under conditions that are arguably the most favourable for it, the case for socialism needs to be made as never before, and it can rest upon a Marxist analysis both for its critique of capitalism and for the light it sheds on the alternatives. With economic and social reproduction increasingly mediated through financialisation, it has become subject to what has been termed the variegated vulnerabilities of everyday (neoliberalised) life, ${ }^{20}$ against which dissent has been as commonplace as it has been fragmented, with increasingly volatile outcomes in the political arena.

\footnotetext{
${ }^{19}$ Itself financialised under contemporary capitalism; see the special issue of New Political Economy, 22 (4), 2017, edited by Bayliss, Fine and Robertson.

${ }^{20}$ See Fine $(2017 \mathrm{c})$.
} 
This is the accepted version of a forthcoming article in Review of Political Economy published by Taylor $\&$ Francis: http://www.tandfonline.com/loi/crpe20

Accepted version downloaded from SOAS Research Online: http://eprints.soas.ac.uk/25262/

Given the scale of issues involved across value theory (from price to crisis theory, from economic to social reproduction), we cannot expect our account to command agreement in general, whether by those who are committed to value theory or those who reject it. What we do hope to have done is at least to have persuaded of the enduring value of value as a category that remains appropriate for analysing contemporary capitalism. The abiding relevance of value theory is that it forges attachments between grand theory and complex and diverse outcomes without descending into eclecticism or rigid determinism, as we have sought to illustrate.

\section{Acknowledgments}

We are grateful to two anonymous referees and the editors for their helpful comments and suggestions. The usual disclaimers apply.

\section{Disclosure statement}

The authors have no financial interest nor benefit arising from the direct application of the research in this article.

\section{References}

Brennan, D.M., Kristjanson-Gural, D., Mulder, C.P. and Olsen, E.K. (eds). 2017. Routledge Handbook of Marxian Economics. London: Routledge.

Christophers, B. 2015. 'The Limits to Financialization.' Dialogues in Human Geography, 5 (2): 183-200.

Christophers, B. 2017. 'Seeing Financialization? Stylized Facts and the Economy Multiple.' Geoforum 85 (October): 259-268.

Dymski, G. 2015. 'How to Engage with the Global Crisis: The Shape of Jazz to Come.' International Initiative for Promoting Political Economy. 29 December 2017. http://iippe.org/wp/wp-content/uploads/2015/10/Dymski-IIPPE-keynote-as-presented.pdf Epstein, G.A. 2005. Financialization and the World Economy. Aldershot: Edward Elgar. Fine, B. 1980. Economic Theory and Ideology. London: Edward Arnold.

Fine, B. (ed.) 1986. The Value Dimension, Marx versus Ricardo and Sraffa. London: Routledge and Kegan Paul. 
This is the accepted version of a forthcoming article in Review of Political Economy published by Taylor $\&$ Francis: http://www.tandfonline.com/loi/crpe20

Accepted version downloaded from SOAS Research Online: http://eprints.soas.ac.uk/25262/

Fine, B. 2008. 'Debating Lebowitz: Is Class Conflict the Moral and Historical Element in the Value of Labour Power.' Historical Materialism 16 (3): 105-114.

Fine, B. 2010. 'Locating Financialisation.' Historical Materialism 18 (2): 97-116.

Fine, B. 2012a. 'Neoliberalism in Retrospect? - It's Financialisation, Stupid.' In

Developmental Politics in Transition: The Neoliberal Era and Beyond, edited by K.-S.

Chang, B. Fine and L. Weiss. London: Palgrave.

Fine, B. 2012b. 'Financialisation and Social Policy.' In Global Crisis and Transformative

Social Change, edited by P. Utting, S. Razavi and R. Buchholz. London: Palgrave.

Fine, B. 2012c. 'Revisiting Rosa Luxemburg's Political Economy.' Critique 40 (3): 423-430.

Fine, B. 2013a. Labour Market Theory: A Constructive Reassessment. London: Routledge, original 1998.

Fine, B. 2013b. 'Consumption Matters.' Ephemera 13 (2): 217-248. 29 December 2017. http://www.ephemerajournal.org/contribution/consumption-matters

Fine, B. 2014a. 'Financialisation from a Marxist Perspective.' International Journal of Political Economy 42 (4): 47-66.

Fine, B. 2014b. 'The Continuing Enigmas of Social Policy', prepared for the UNRISD project on Towards Universal Social Security in Emerging Economies, UNRISD Working Paper 2014-10. 29 December 2017. http://www.unrisd.org/Fine

Fine, B. 2016. The Endemic and Systemic Malaise of Mainstream Economics. FESSUD Working Paper Series No. 190. 29 December 2017.

http://fessud.eu/wp-content/uploads/2015/03/FESSUD_WP190_The-EndemicSystemicMalaise-of-Mainstream-Economics.pdf

Fine, B. 2017a. 'The Material and Culture of Financialisation.' New Political Economy 22 (4): $371-382$.

Fine, B. 2017b. 'A Note towards an Approach towards Social Reproduction.' International Initiative for Promoting Political Economy. 29 December 2017. http://iippe.org/wp/wpcontent/uploads/2017/01/sroverviewben.pdf

Fine, B. 2017c. 'The Continuing Enigmas of Social Policy.' In Towards Universal Health Care in Emerging Economies: Opportunities and Challenges, edited by I. Ye. London: Palgrave.

Fine, B. 2017d. 'Neither Equilibrium as Such nor as Abstraction: Debating Fred Moseley's Transformation.' International Journal of Political Economy 46 (1): 22-28. 
This is the accepted version of a forthcoming article in Review of Political Economy published by Taylor $\&$ Francis: http://www.tandfonline.com/loi/crpe20

Accepted version downloaded from SOAS Research Online: http://eprints.soas.ac.uk/25262/

Fine, B. and Hall, D. 2012. 'Terrains of Neoliberalism: Constraints and Opportunities for Alternative Models of Service Delivery.' In Alternatives to Privatization: Exploring NonCommercial Service Delivery Options in the Global South, edited by D. McDonald and G. Ruiters. London: Routledge.

Fine, B. and Harris, L. 1979. Rereading 'Capital'. London: Macmillan.

Fine, B. and Saad-Filho, A. (eds) 2013. The Elgar Companion to Marxist Economics.

Aldershot: Edward Elgar.

Fine, B. and Saad-Filho, A. 2016. Marx's 'Capital' $6^{\text {th }}$ edition. London: Pluto Press.

Fine, B. and Saad-Filho, A. 2017. 'Thirteen Things You Need to Know About

Neoliberalism.' Critical Sociology 43 (4-5): 685-706.

Fine, B., Bayliss, K., Robertson, M. and Saad-Filho, A. 2018. Neoliberalism,

Financialisation and Welfare: The Political Economy of Social Provision in the UK.

Aldershot: Edward Elgar (forthcoming).

Howard, M.C. and King, J. 1989, 1991. A History of Marxian Economics, 2 Vols. Princeton:

Princeton University Press.

Lebowitz, M. 2006. 'The Politics of Assumption, the Assumption of Politics.' Historical Materialism 14 (2): 29-47.

Lebowitz, M. 2010. 'Trapped inside the Box? Five Questions for Ben Fine.' Historical Materialism 18 (1): 131-149.

Michell, J. and Toporowski, J. 2014. 'Critical Observations on Financialization and the

Financial Process.' International Journal of Political Economy 42 (4): 67-82.

Moseley, F. 2015. Money and Totality. Leiden: Brill.

Radin, M. 1996. Contested Commodities. Cambridge, MA: Harvard University Press.

Saad-Filho, A. 2002. The Value of Marx. London: Routledge.

Saad-Filho, A. 2017. 'Neoliberalism.' In The Routledge Handbook of Marxian Economics, edited by D. M. Brennan, D. Kristjanson-Gural, C. Mulder, E. Olsen. London: Routledge. Samuelson, P.A. 1966. 'A Summing Up.' Quarterly Journal of Economics 80 (4): 568-583. Samuelson, P.M. 1971. 'Understanding the Marxian Notion of Exploitation, A Summary of the So-Called Transformation Problem Between Marxian Values and Competitive Prices.' Journal of Economic Literature 9 (2): 399-431.

Shaikh, A. 2016. Capitalism: Competition, Conflict, Crises. Oxford: Oxford University Press. Sweezy, P. 1968. The Theory of Capitalist Development. New York: Monthly Review Press. Steedman, I. 1977. Marx after Sraffa. London: New Left Books. 
This is the accepted version of a forthcoming article in Review of Political Economy published by Taylor $\&$ Francis: http://www.tandfonline.com/loi/crpe20

Accepted version downloaded from SOAS Research Online: http://eprints.soas.ac.uk/25262/

Steedman, I. (ed.) 1981. The Value Controversy, London: Verso.

Zelizer, V. 1994. Pricing the Invaluable Child: The Changing Social Value of Children. Ithaca: Princeton University Press. 